Research Article

\title{
The Use of Lumbricus Rubellus Earthworm Effect in Composting Process of Musa Paradisiaca L. Peel Waste
}

\author{
Vely Kukinul Siswanto', Vivin Setiani2*, Ayu Nindyapuspa², Ummi Fadlilah \\ Kurniawati', Mayang Mutiara Kamilah'
}

'Department of Urban and Regional Planning, Sepuluh Nopember Institute of Technology, Street on Despro, Gedung A Lantai 2 Kampus ITS, Sukolilo Surabaya

${ }^{2}$ Study Programe of Waste Treatment Engineering, Department of Marine Engineering, Shipbuilding Institute of Polytechnic Surabaya, Street on Teknik Kimia, Kampus ITS Sukolilo, Surabaya

*Corresponding author, e-mail: vivinsetiani@ppns.ac.id

\begin{abstract}
Conventional organic waste composting is one of the processing of organic waste that produces fertilizer. However, the conventional composting process for organic waste lasts 1-3 months. Vermicomposting is composting that lasts a short time, and in addition, vermicomposting produces compost and worms with a high selling value. So, in this study, Musa Paradisiaca L (MPL) peel and sawdust waste were composted using the vermicomposting method into compost. The primary data in this study consisted of monitoring the $\mathrm{C} / \mathrm{N}$ ratio, temperature, $\mathrm{pH}$, moisture content, texture, the particle size of compost for 3 weeks of the composting process. Testing the analysis of the effect of using Lumbricus Rubellus (LR) earthworms in the composting process of MPL peel waste and sawdust by using LR earthworms. The study results showed that LR worms had no effect on temperature, $\mathrm{pH}$, water content, and $\mathrm{C} / \mathrm{N}$ ratio during the composting process of MPL peel waste but did affect the texture, particle size, and product of compost weight. $\mathrm{pH}$, moisture content, and temperature of compos with adding LR earthworms and without LR worms was 7, less than 50\%, 27-29 oC, respectively. The C/N ratio of compost that uses $L R$ earthworms was 28 , while the $C / N$ ratio of composting that uses $L R$ earthworms was 33 .
\end{abstract}

Keywords: Musa Paradisiaca L waste; sawdust waste; vermicomposting

\section{Introduction}

Banana (Musa paradisiaca L.) is the main fruit commodity in Southeast Asian countries, especially in Indonesia. In 2007, the total production of bananas in Indonesia was 5,270,131 tons (Suhartanto et al., 2012). In 2017, banana production increased, reaching 6.8 million tons (Mujiyo et al., 2017). Around $90 \%$ of the banana harvest in Indonesia gets a lot of demand from the domestic market, especially for star hotels and supermarkets (Suhartanto et al., 2012). This abundant banana production can cause new problems. Most of the wasted banana peels are agricultural waste that can cause environmental pollution (Hartono and Janu 2013). Besides being agricultural waste, banana peel waste is also part of household waste due to the high consumption of bananas (Nuriasih et al., 2019). Therefore, a technology to reduce the banana peel waste generation is needed. One method that can reduce banana peel waste generation is composting. 
Aerobic composting can reduce the volume of organic waste by up to $50 \%$. The aerobic composting process takes 20 to 30 days. The $\mathrm{C} / \mathrm{N}$ ratio is an essential factor in the composting process. The optimum range of $\mathrm{C} / \mathrm{N}$ ratio required for most organic waste is $20-25$. The optimum moisture content for composting is around 50-6o percent (Tchobanoglous et al., 2002). $\mathrm{C} / \mathrm{N}$ ratio for banana peel is 40 (Suprianto \& Erlani, 2019). The water content in banana peels is $76 \%$ (Arthawidya et al., 2017). Because the $\mathrm{C} / \mathrm{N}$ ratio of banana peels is high, it is necessary to carry out technological engineering to make them into compost. One such technology is vermicomposting.

Vermicomposting is one of the methods to decompose organic material for less than 30 days, decrease the $\mathrm{C} / \mathrm{N}$ ratio, and retain nitrogen more than conventional composting (Wulandari, 2020). They added earthworms called Lumbricus Rubellus (LR) as decomposers increase composting rate process on organic solid waste (Rahmawati and Herumurti,2016). The growth of LR earthworms needs bedding, making organic waste fast degradation. Sawdust was needed as a bedding and bulking agent to increase the carbon value in vermicomposting process (Subandriyo et al., 2012). Sawdust contains water content 12.36\%, $\mathrm{N}$ total (o.48\%), C-organic (52.97\%), C/N ratio (110).

Vermicomposting is a biotechnology method involving earthworms as a natural bioreactor to effectively recycle solid waste and organic wastewater (Bhandarkar, 2004). The novelty of this research is to increase the value of the composting product. In the previous research, the composting product was just the compost itself. The composting products are the composting itself and the bigger earthworm with vermicomposting. The nutrition of compost materials obtains the growth of earthworms. This research A nine grams earthworms Lumbricus rubellus on six hundred grams organic solid waste decomposed landscape waste up to $14.35 \%$ and increased the nitrate concentration up to 34\% (Rahmawati and Herumurti, 2016). EM4 as a bio activator will increase the composting process rate and less odor (Natalina et al., 2017). This research aims to analyze the quality of compost products (color, texture, particle size, odor, $\mathrm{C} / \mathrm{N}$ ratio, phosphor, potassium, $\mathrm{pH}$ ) and the growth of earthworms because of the vermicomposting process MPL peel.

\section{Methodology}

Before vermicomposting was conducted, the $\mathrm{C} / \mathrm{N}$ ratio of MPL peels and sawdust were analyzed to obtain the composition of compost material. C-organic and total Nitrogen of MPL peel and sawdust were analyzed by Walkey and Black method and Kjeldahl method, respectively. The result of C-organic and total Nitrogen value of MPL peel and sawdust were shown in Table 1.

Table 1. C-organic and total nitrogen value of MPL peels and sawdust

\begin{tabular}{cccc}
\hline Material & C-organic Value (\%) & $\begin{array}{c}\text { Total Nitrogen Value } \\
(\%)\end{array}$ & C/N ratio \\
\hline MPL Peels & 45.46 & 0.55 & 82 \\
Sawdust & 52.97 & 0.48 & 110 \\
\hline
\end{tabular}

After the $\mathrm{C} / \mathrm{N}$ ratio of MPL peel and sawdust were calculated, the composition of compost material was calculated using Equation 1 (Tchobanoglous et al., 2002).

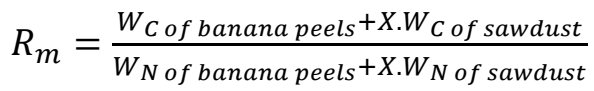

Where :

$\mathrm{Rm} \quad=\mathrm{C} / \mathrm{N}$ ratio of the mixture of MPL peel and sawdust

$\mathrm{W}_{\mathrm{C}} \quad=$ Weight of carbon

$\mathrm{W}_{\mathrm{N}} \quad=$ Weight of nitrogen

$\mathrm{X} \quad=$ weight of sawdust mixed with $1 \mathrm{~kg}$ MPL peel waste

According to Biruntha et al. (2020), using the $\mathrm{C} / \mathrm{N}$ ratio gave nutrition for LR earthworms on the vermicomposting process. With $\mathrm{C} / \mathrm{N}$ ratio mix $(\mathrm{Rm})$ was 82 obtained that the weight of sawdust (o.o2 
$\mathrm{kg}$ ) was mixed with $1 \mathrm{~kg}$ of MPL peel waste so that the percentage composition of the composted waste in this study consisted of sawdust (2\%) and MPL peel waste (98\%).

In this study, the density of the compost materials was measured to calculate the volume of the compost mixture. The compositions used in this research are $98 \%$ MPL peel waste and $2 \%$ sawdust without LR earthworms (B1), and 250 gr LR earthworms / $/ \mathrm{kg}$ organic waste (B2). Measurement of the compost mixture density using the Indonesian National Standard number 19-3964-1994. Based on the measurement of the density of the compost materials, the density of the compost mixture and the mass of composted waste in reactors 1 and 2 were $572 \mathrm{~kg} / \mathrm{m}_{3}$ and $12.24 \mathrm{~kg} / \mathrm{m}_{3}$, respectively.

The type of reactor in this study was a cubical continuous flow bin type. This reactor was made of wood and surrounded by sacks and cloth, which maintains humidity and air circulation in the reactor. The reactor is covered with a para net so that oxygen availability is sufficient in the composting process. The volume of the composting reactor used in this study was $85504 \mathrm{~cm} 3$, four times bigger than the volume of compost material). The height and width of the reactor have the same length, which was $50 \mathrm{~cm}$. The design of the reactor of vermicomposting is shown in Figure 1.

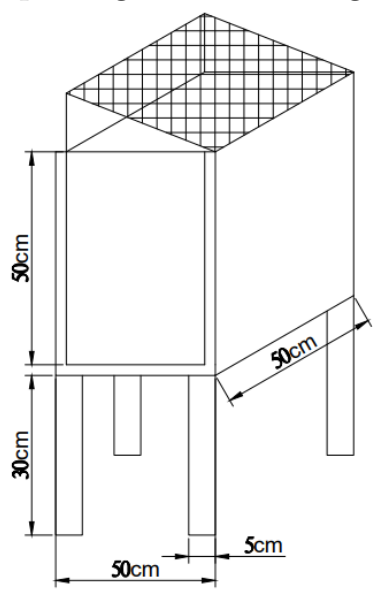

Figure 1. Reactor of vermicomposting

Banana peels were chopped into sizes 2-3 $\mathrm{mm}$. After that, MPL peels were mixed with sawdust homogeneously. The MPL peel and sawdust mixture were put into reactors 1 and 2. Each reactor was added $\mathrm{EM}_{4}$ with a dosage of $30 \mathrm{~mL} / \mathrm{kg}$ compost material. The $2.76 \mathrm{~kg}$ earthworms were added into reactor 2 ( $\mathrm{B} 2)$. Composting has been going for three weeks.

The composting process's $\mathrm{pH}$, temperature, moisture content, texture, and color were monitored every day. Particle size, the growth of earthworms was measured after 3 weeks. C-organic, total nitrogen, phosphor, and potassium were analyzed at $1^{\text {st }}$ week and $3^{\text {rd }}$ weeks. The methods that were used are shown in Table 2.

Table 2. Physical and chemical analysis methods

\begin{tabular}{ll}
\hline \multicolumn{1}{c}{ Parameters } & \multicolumn{1}{c}{ Measurement Method } \\
\hline pH dan temperature & In situ \\
Moisture content & Gravimetric \\
Texture and color & In situ \\
Particle size & In situ \\
weight of LR earthworm and compost & In situ \\
C-Organik & Walkey and Black \\
Total N & Kjhedahl Nitrogen \\
& Spectrophotometry \\
Phospor & Atomic Absorption Spectrophotometry (AAS) \\
\hline
\end{tabular}


The physical and chemical analysis results were analyzed statistically-the statistical analysis used ANOVA One Way. Before the statistic test was conducted, normality test with Anderson darling method and homogeneity test with Levene method were conducted first (as shown in Table 8). Parameters tested for their effect during the composting process were $\mathrm{pH}$, temperature, moisture content, $\mathrm{C} / \mathrm{N}$ ratio. The hypothesis of this research was as follows.

HoA $=$ there was no effect of the use of LR earthworms in temperature of the composting process

$\mathrm{H}_{\mathrm{A}}=$ there was the effect of the use of LR earthworms in temperature of the composting process

$\mathrm{Ho}_{\mathrm{B}}=$ there was no effect of the use of LR earthworms in $\mathrm{pH}$ of the composting process

$\mathrm{H}_{\mathrm{B}}=$ there was the effect of the use of LR earthworms in $\mathrm{t} \mathrm{pH}$ of the composting process

$\mathrm{Hoc}=$ there was no effect of the use of LR earthworms in moisture content of the composting process

$\mathrm{Hic}_{1 \mathrm{C}}$ there was the effect of the use of LR earthworms in moisture content of the composting process

HoD $=$ there was no effect of the use of LR earthworms in the $\mathrm{C} / \mathrm{N}$ ratio of composting

$\mathrm{H}_{1 D}=$ there was the effect of the use of LR earthworms in the $\mathrm{C} / \mathrm{N}$ ratio of composting

\section{Result and Discussion}

\subsection{Temperature of Compost}

This study showed that the composting temperature occurred at a decrease to soil temperature (300 C) at $\mathrm{B}_{1}$ and $\mathrm{B}_{2}$. There was only a slight difference in the composting temperature of the two reactors. Figure 2 showed that the composting temperature in both reactors is in the range (27-370 C). The optimal temperature for earthworm growth was in the range of 15-370 C (Kendie, 2009, Manyuchi et al. 2012 and Chaoui, 2010). According to Meena et al. 2021, the composting process has a mesophilic phase (temperature rise to $450 \mathrm{C}$, thermophilic and hygienic ( $45-600 \mathrm{C})$, and mesophilic $2(<400 \mathrm{C})$ and maturation (20-300 C).

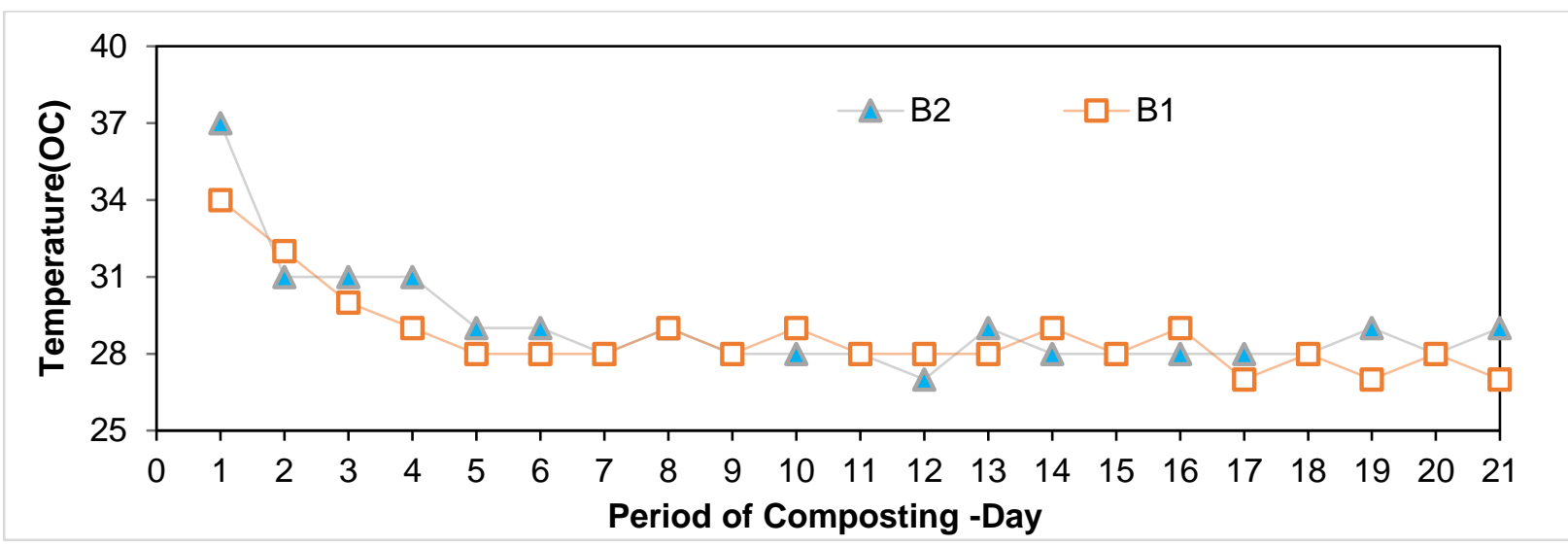

Figure 2. Temperature measurements in the composting process

In this study, there was no difference between the $\mathrm{pH}$ of the composting process in $\mathrm{B} 1$ and $\mathrm{B} 2$ (can be seen in Figure 3). There was no difference in the composition and type of compost material in B1 and $\mathrm{B}_{2}$ (Himanen and Hänninen, 2011). At the beginning of composting, the $\mathrm{pH}$ decreased, indicating the decomposition process of microorganisms produces organic acids and produces $\mathrm{CO}_{2}$ from the activities of microorganisms (González et al., 2019). On the 4th day of $\mathrm{pH}$, composting rose to 7 , and this was due to the activity of microorganisms in decomposing organic compounds into amides, amino acids, and ammonium into ammonia (Gusmawartati and Yusuf, 2015). According to Khaerunnisa and Rahmawati (2013) the increase of nitrogen compounds as ammonium $\left(\mathrm{N}_{-} \mathrm{NH}_{4}{ }^{+}\right)$indicates that the composting process is going well. 


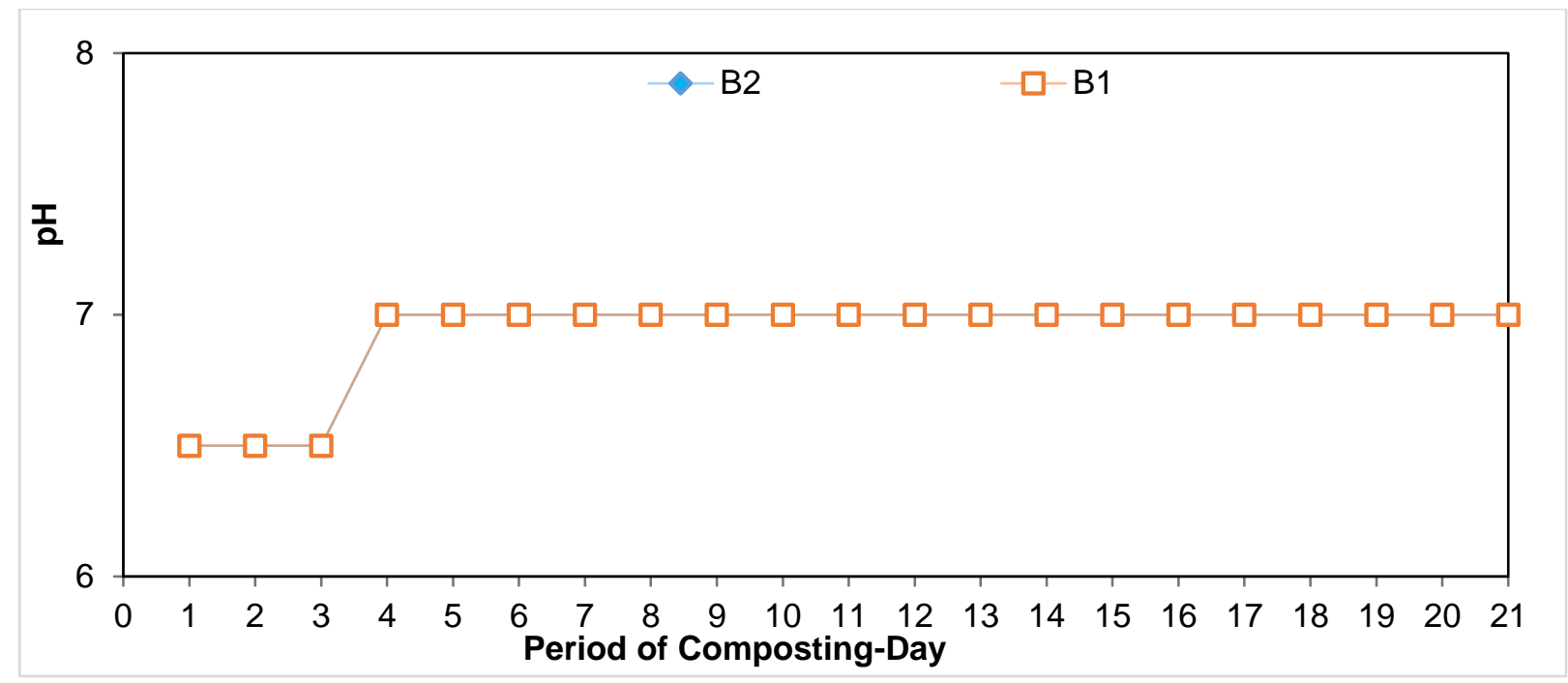

Figure 3. $\mathrm{pH}$ measurements in the composting process

\subsection{Color, Texture, and Particle Size of Compost}

This study compared the physical condition of the compost from the results of composting using 250 grams of LR earthworm $/ \mathrm{kg}$ waste and without LR earthworm. Worms used in composting can speed up the composting process. This was shown in the results of observations on both reactors. Compost began to form in the reactor that did not use worms on the $15^{\text {th }}$ day. Compost began to form in the reactor that used worms on the 12th day. It was characterized by the color and texture of the compost, which began to turn blackish brown and smooth. The waste condition in the two reactors was the same, which was bright, fresh, and had a rough texture. Although the compost located in B2 was faster than in reactor $\mathrm{B} 1$, the color and texture had not changed again after the $2 \mathrm{1}^{\text {st }}$ day. The results of observing the color and texture of compost fertilizer can be seen in Table 3 .

Table 3. Results of observation of color and texture of compost fertilizer

\begin{tabular}{|c|c|c|c|c|}
\hline \multirow{2}{*}{ Day } & \multirow{2}{*}{ B1 } & \multirow{2}{*}{ B2 } & \multicolumn{2}{|c|}{ Picture } \\
\hline & & & B1 & $\mathbf{B}_{2}$ \\
\hline \multirow{2}{*}{1} & Bright and fresh color & $\begin{array}{l}\text { Bright and fresh color } \\
\text { Coarse texture }\end{array}$ & & \\
\hline & Coarse texture & Coarse texture & & \\
\hline 3 & $\begin{array}{l}\text { Bright and fresh color and rough } \\
\text { texture }\end{array}$ & $\begin{array}{l}\text { Bright and fresh color } \\
\text { Coarse texture }\end{array}$ & & \\
\hline \multirow[b]{2}{*}{6} & Light brown color & Dark chocolate & & \\
\hline & Slightly rough texture & Coarse texture & & \\
\hline \multirow[b]{2}{*}{9} & Dark brown color & Dark chocolate & & \\
\hline & Slightly rough texture & Coarse texture & & \\
\hline \multirow[b]{2}{*}{12} & Dark chocolate & Dark chocolate & & \\
\hline & Slightly rough texture & Slightly smooth texture & & \\
\hline \multirow[b]{2}{*}{15} & Dark chocolate & Dark chocolate & & \\
\hline & Slightly smooth texture & Smooth texture & & \\
\hline \multirow{2}{*}{18} & Dark chocolate & Dark chocolate & & \\
\hline & Smooth texture & Smooth texture & & \\
\hline \multirow{2}{*}{21} & Dark chocolate & Dark chocolate & & \\
\hline & Smooth texture & Smooth texture & & \\
\hline
\end{tabular}

There were differences in the particle size of the compost in $\mathrm{B}_{1}$ and $\mathrm{B}_{2}$. The particle size in the first and second reactors was compared with SNI 19-7030-2004 regarding compost quality. Fertilizer must have a particle size maximum of $25 \mathrm{~mm}$ of the weight of compost. The compost that was formed on the 21st day was harvested and sifted. Sifting was carried out to separate the finished compost from the waste that had not been composted or was still lumpy. The sieving in reactor B2 aims to separate the 
compost from the LR earthworms. After sieving, the compost was analyzed for particle size. Based on the research results, the particle size of the compost in both reactors was $2 \mathrm{~mm}$. The percentage of particle size of $2 \mathrm{~mm}$ in compost in B1 was $76 \%$, while the percentage of $2 \mathrm{~mm}$ in compost in $\mathrm{B} 2$ was $85 \%$. This proves that the use of LR earthworms in composting or vermicomposting can help reduce the particle size of the compost. The utilization of LR earthworms in the composting process can improve the compost's physical quality in terms of color, texture, and particle size. The results of the observation of the particle size of the compost using the vermicomposting method can be seen in Table 4 .

Table 4. The particle size of the compost

\begin{tabular}{|c|c|c|}
\hline Reactor & Particle size (SNI 19-7030-2004) & The particle size of the compost \\
\hline B1 & Maximum $25 \mathrm{~mm}$ & $2 \mathrm{~mm}(76 \%)$ \\
\hline $\mathrm{B}_{2}$ & & $2 \mathrm{~mm}(85 \%)$ \\
\hline
\end{tabular}

\subsection{C/N ratio, C-Organic, N, P, and K of Compost}

Figure 5 described that the $\mathrm{C} / \mathrm{N}$ ratio in the composting reactor $\mathrm{B}_{1}$ was higher than that of the $\mathrm{B}_{2}$ reactor. This was due to the higher nitrogen content in composting process with adding earthworms (Rahmatullah et al., 2013). According to Favoretto et al (2016), the decrease in nitrogen was due to the denitrification process into ammonium carried out by earthworms. When compared with SNI 19-7030 2004, the value of the $\mathrm{C} / \mathrm{N}$ ratio in reactors $\mathrm{B} 1$ and $\mathrm{B} 2$ did not qualify SNI. This was because the raw material for this compost was MPL peel waste. Based on the study results, the initial $C$ value of MPL peel waste was $45.46 \%$, while the organic N value of MPL peel waste was $0.55 \%$. The initial C/N ratio of MPL peel waste was 82 (Table 1). MPL peel waste contained high cellulose, so the $C$ content was more significant than the $\mathrm{N}$ value, so the $\mathrm{C} / \mathrm{N}$ ratio was large.

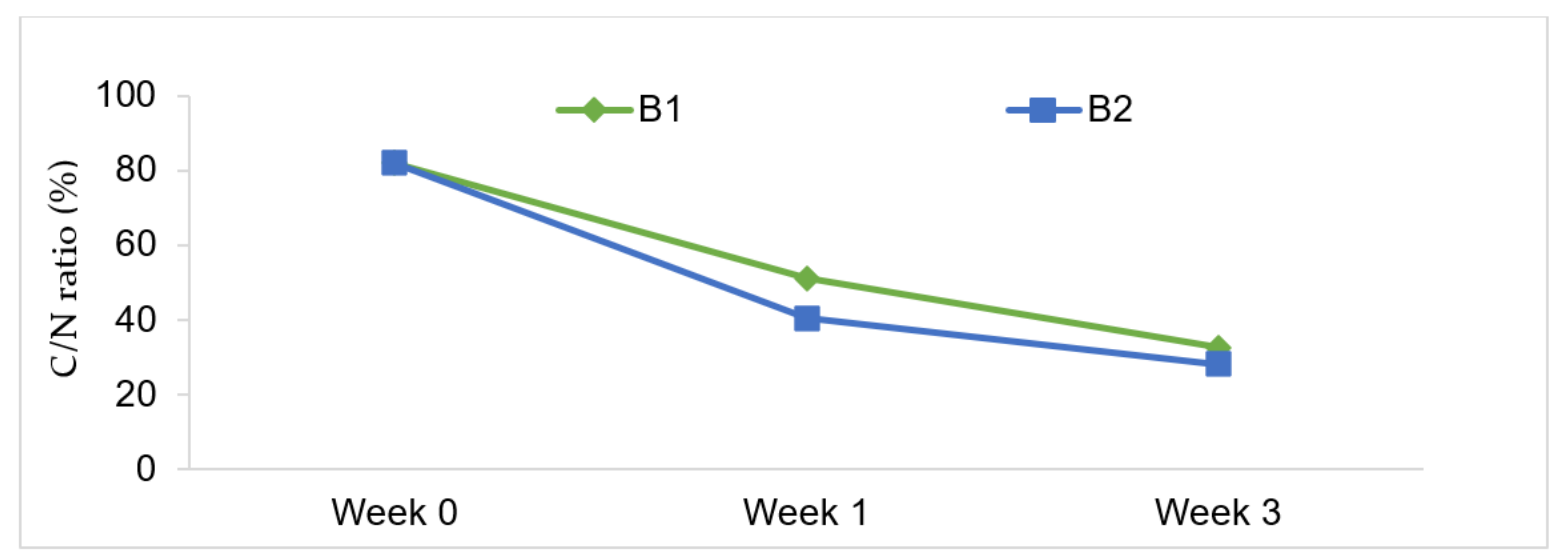

Figure 5. $\mathrm{C} / \mathrm{N}$ ratio of the composting process

Compost's $\mathrm{C}, \mathrm{N}, \mathrm{P}$, and $\mathrm{K}$ values qualified SNI 19-7030 2004. However, the $\mathrm{C} / \mathrm{N}$ ratio in compost did not qualify SNI 19-7030 2004. It is because the $C$ value was still relatively high. Therefore, the composting process needs to be carried out for more than three weeks so that the $\mathrm{C}$ value can be further decreased so that the $\mathrm{C} / \mathrm{N}$ ratio can qualify the requirements. Although the $\mathrm{C} / \mathrm{N}$ ratio did not qualify the requirements, the compost product produced has met the requirements when viewed from its physical characteristics (color, odor, texture, and particle size). This research should be vermicomposting process long time than 3 weeks. According to Purnomo et al (2017), Chaniago and Yulita (2020) and Bakar et al (2014), C/N ratio compost meets SNI because of vermicomposting for eight weeks. The longer the vermicomposting process, the greater the decomposition of carbon compounds into $\mathrm{CO}_{2}$ gas. This causes the $\mathrm{C}$ - Organic content to decrease and the $\mathrm{C} / \mathrm{N}$ ratio to decrease. The composition of the waste and the time of composting improved the quality of worms, reducing $\mathrm{C}$-organic as the $\mathrm{N}$ value increases rapidly. Therefore, the best $\mathrm{C} / \mathrm{N}$ ratio in vermicomposting was 15 (Jamaludin et al., 2010). 
The composting time factor can be considered one of the factors that affect the difference in the concentration of N, P, and K. A longer composting period gave a longer treatment process. This caused the concentration values of $\mathrm{N}, \mathrm{P}$, and $\mathrm{K}$ to increase along with the length of the composting process. The longer the time required for vermicomposting, the greater the $\mathrm{N}, \mathrm{P}$, and $\mathrm{K}$ concentration obtained. For comparison, in Othman et al. (2021) study, the N, P, and $\mathrm{K}$ values in vermicomposted compost for 14 consecutive days were $0.197 \%$; $0.0285 \%$; and $0.0136 \%$. The content of $\mathrm{N}, \mathrm{P}$, and $\mathrm{K}$ in the compost produced in $\mathrm{B}_{1}$ and $\mathrm{B}_{2}$ complies with SNI 19-7030 2004. This indicates that the compost produced in reactors $\mathrm{B}_{1}$ and $\mathrm{B}_{2}$ can be used for plant growth (Table 5 ).

Table 5. NPK measurement results in compost

\begin{tabular}{lcccc}
\hline Element & SNI 19-7030 2004 (minimum) & B1 & B2 & Analyzis \\
\hline Nitrogen (\%) & 0.4 & 1.17 & 0.96 & Qualified \\
$\mathrm{P}_{2} \mathrm{O}_{5}(\%)$ & 0.1 & 0.57 & 0.5 & Qualified \\
$\mathrm{K}_{2} \mathrm{O}(\%)$ & 0.2 & 0.52 & 0.5 & Qualified \\
\hline
\end{tabular}

\subsection{Test the Effect of Using LR Earthworms on $\mathrm{pH}$, Temperature, Moisture Content, and $\mathrm{C} / \mathrm{N}$ Ratio in Composting Process}

The test results of the effect of using LR earthworm ( $250 \mathrm{gr} / \mathrm{Kg}$ compost material) LR were as follows.

Table 6. The test of the effect of using LR earthworm

\begin{tabular}{|c|c|c|c|c|c|c|}
\hline \multirow{2}{*}{ Test } & \multicolumn{2}{|c|}{ Normality Test } & \multicolumn{2}{|c|}{ Homogeneity Test } & \multicolumn{2}{|c|}{ Statistic Test } \\
\hline & Method & P-Value & Method & P-value & Method & P-value \\
\hline Temperature & $\begin{array}{c}\text { Anderson } \\
\text { Darling }\end{array}$ & 0.005 & Levene & 0.671 & $\begin{array}{c}\text { One Way } \\
\text { Anova }\end{array}$ & 0.469 \\
\hline $\mathrm{pH}$ & $\begin{array}{c}\text { Anderson } \\
\text { Darling }\end{array}$ & 0.005 & Levene & 1 & $\begin{array}{c}\text { One Way } \\
\text { Anova }\end{array}$ & 1 \\
\hline $\begin{array}{l}\text { Moisture } \\
\text { Content }\end{array}$ & $\begin{array}{c}\text { Anderson } \\
\text { Darling }\end{array}$ & 0.008 & Levene & 0.653 & $\begin{array}{c}\text { One Way } \\
\text { Anova }\end{array}$ & 0.862 \\
\hline C/N Ratio & $\begin{array}{c}\text { Anderson } \\
\text { Darling }\end{array}$ & 0.335 & Levene & 0.642 & $\begin{array}{c}\text { One Way } \\
\text { Anova }\end{array}$ & 0.547 \\
\hline
\end{tabular}

Table 6 showed that the addition of LR earthworms ( $250 \mathrm{gr} / \mathrm{Kg}$ compost material) had no effect (P-value $>\alpha 0,05$ ) on temperature, $\mathrm{pH}$, moisture content, and $\mathrm{C} / \mathrm{N}$ ratio of composting. This was because the composting process was not long (only 3 weeks), and the levels of earthworms in the composting process were not high enough. It did not affect the temperature, $\mathrm{pH}$, or water content $\mathrm{C} / \mathrm{N}$ ratio of MPL peel waste composting. The results of this study were different from the results of research by González et al (2019) where the pineapple peel composting process with the vermicomposting method lasts for 9 weeks so that it affects the $\mathrm{pH}$, temperature, and water content of the compost.

\subsection{Weight of LR Earthworm and Compost}

In this study, the weight of MPL peel waste and composted sawdust was $12.24 \mathrm{~kg}$. In reactor B2, the weight of the worm added was $2.76 \mathrm{~kg}$. After composting for 3 weeks, there was a decrease in the waste and an increase in the weight of the LR earthworms. The percentage of waste shrinkage in reactor B1 reached $66.5 \%$, and the percentage of waste shrinkage in reactor B2 reached 70.59\%. Compost shrinkage in reactor $\mathrm{B}_{2}$ was more significant than the shrinkage of waste in reactor B1. This shows that the LR earthworms added in B2 could consume waste well, so the depreciation value was large. The graph of compost shrinkage and worm weight gain can be seen in Figure 6. 


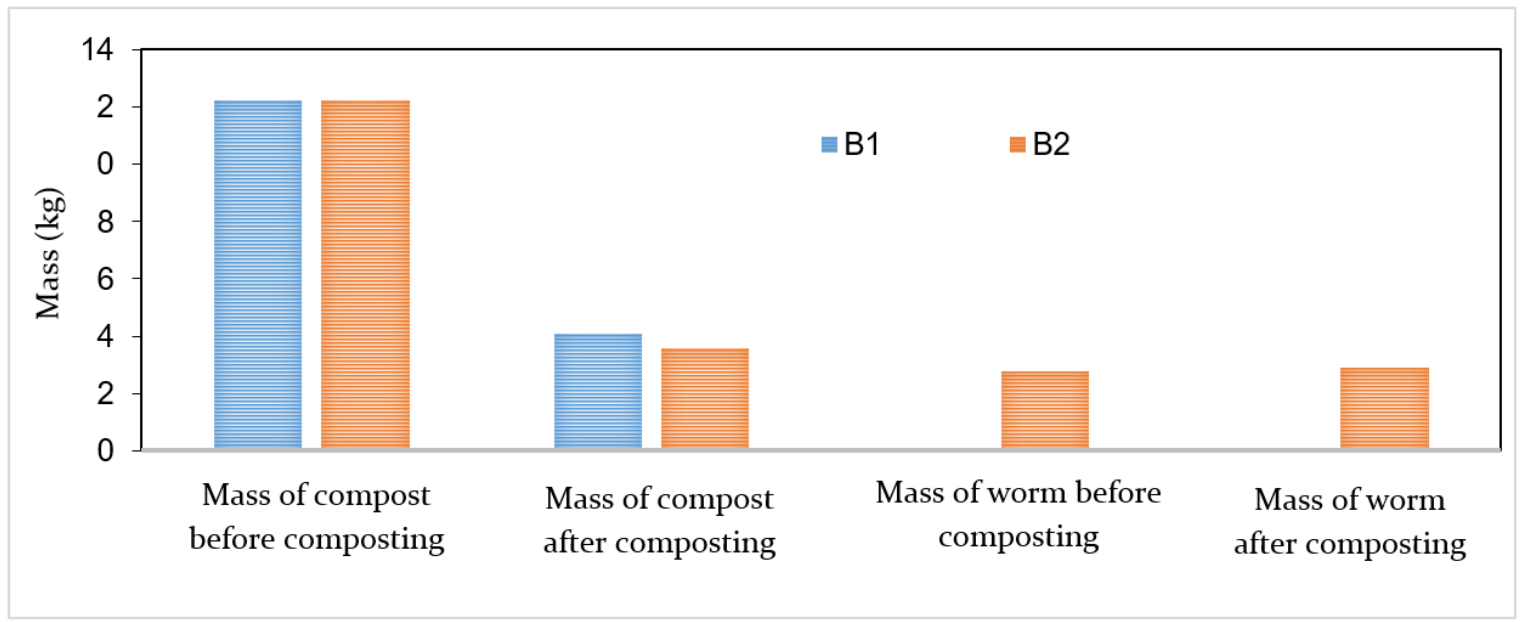

Figure 6. Weight of compost and LR earthworms before and after the composting process (21 days)

\section{Conclusion}

After conducting research, it can be concluded that the addition of LR earthworms of $250 \mathrm{~g} / \mathrm{Kg}$ of compost material in composting MPL peel waste does not affect temperature, $\mathrm{pH}$, water content, and $\mathrm{C} / \mathrm{N}$ ratio. However, it affects the resulting compost's texture, particle size, and weight. The characteristic of compost with adding LR earthworms and without LR worms was almost the same $\mathrm{pH}$ average 7 , moisture content less than 50\%, and temperature of compost $27-29 \mathrm{oC}$, respectively. The $\mathrm{C} / \mathrm{N}$ ratio of compost that uses $L R$ earthworms was 28 , while the $C / N$ ratio of composting that uses $L R$ earthworms was 33. Further research should be vermicomposting process should be a longer time than 3 weeks to affect temperature, $\mathrm{pH}$, water content, and $\mathrm{C} / \mathrm{N}$ ratio compost and could meet SNI 19-70302004. In addition, the vermicomposting process should be use LR worms less than 1 year old.

\section{Acknowledgment}

Thank you to the Direktorat Riset dan Pengabdian Kepada Masyarakat of Institute Tecnology of Sepuluh Nopember (ITS) supported fee of Pengabdian Masyarakat in 2021.

\section{References}

Arthawidya, J. Sutrisno, E. and Sumiyati, S. 2017. Analisis komposisi terbaik dari variasi C/N rasio menggunakan limbah kulit buah pisang, sayuran dan kotoran sapi dengan parameter c-organik, n-total, phospor, kalium dan $\mathrm{c} / \mathrm{n}$ rasio menggunakan metode vermikomposting. Teknik Lingkungan 6(3), 1-20.

Badan standart Nasional. 2004. Spesifikasi kompos dari sampah organik domestik. SNI 19-7030-2004.

Badan standart Nasional. 1994. Metode pengambilan dan pengukuran contoh timbulan dan komposisi sampah perkotaan. SNI 19-3964-1994.

Bakar. Azizi A. Gawi. Syarufah N. A.S. M. Mahmood, N. Z. and Abdullah, N. 2014. Vermicomposting Of vegetable waste amended with different sources of agro-industrial by-product using Lumbricuss Rubellus. Polish Journal Environmental Studies 23 (5), 1491-1498.

Biruntha M, N.Karmegam, J.Archana, B.K.Selvi, J.A.J. Paul, B.Balamuralikrishnan, S.W.Chang, B.Ravindran. 2020. Vermiconversion of biowastes with low-to-high $\mathrm{c} / \mathrm{n}$ ratio into value added vermicompost. Bioresource Technology 297, 122398.

Chaoui, H. 2010. Vermicasting (or vermicomposting): processing organic wastes through earthworms, factsheet. Agreement of Differential Gene Expression (ADGEX), 743/537.

Chaniago, N. 2018. Uji beberapa jenis bahan organik dan lamanya proses vermicomposting terhadap kuantitas dan kualitas casting. Agrica Ekstensi 12 (2), 18-25. 
Favoretto, L.P. Ademola, A.E. Abosede, O.O. Vinicius, B.A. and Oliveria, R.M.O. 2016. Chemical study of vermicomposted agroindustrial wastes. Recycle Organic Waste Agriculture 5, 55-63.

González, Eduardo, C. Mario, R.G-D. Lorena D. M-S. and Marcela, P. S-C. 2019. Pre-Composting and vermicomposting of pineapple (ananas comosus) and vegetable waste. Applied Science Multidisciplinary Digital Publishing Institute 9(17), 3564.

Gupta, R. and Garg, V.K. 2017. Vermitechnology for organic waste recycling. Current Developments in Biotechnology and Bioengineering Solid Waste Management, 83-112.

Gusmawartati. and Yusuf, M. 2015. Effect various combination of organic waste on compost quality hapsoh. Journal of Tropical Soils 20 (1), 59-65.

Hartono, A. and Janu, P. B. 2013. Pelatihan pemanfaatan limbah kulit pisang sebagai bahan dasar pembuatan kerupuk. jurnal inovasi dan kewirausahaan 2(3), 198-203.

Himanen. M. and Hänninen K. 2011. Composting Of bio-waste, aerobic and anaerobic sludges-effect of feedstock on the process and quality of compost. Bioresource Technology 102, 2842-2852.

Jamaludin, A. Ainurzaman. and Noor, Z. Mahmood. 2010. Effects of vermicomposting duration on macronutrient elements and heavy metals concentrations in vermicompost. Sains Malaysiana 39(5), 711-715.

Kendie, A.H. 2009. Effects of carbon to nitrogen ratio on vermicomposting of rice husk and cow dung with fresh biosolid. Master's Thesis, Mekelle University, Mekele, Etiopia.

Khaerunnisa, G. and Rahmawati, I. 2013. Pengaruh pH dan rasio COD: N terhadap produksi biogas dengan bahan limbah industri alkohol (vinasse). Teknologi Kimia dan Industri 2, 1-7.

Majlessi, M. Eslami, AN. H.S. Mirshafieean, S. Babaii, S. 2012. Vermicomposting of food waste: assessing the stability and maturity. Journal Environmental Health Science and Engineering 9, 25.

Manyuchi, M.M.M. Phiri, A. Chirinda, N. Muredzi, P. Govhaand, J. Sengudzwa, T. 2012. Vermicomposting of waste corn pulp blended with cow dung using eisenia foetida. World Academy of Science Engineering and Technology 68, 1306-1309.

Meena, A. L. Minakshi, K. Debashis, D. R.P., and Mishra. 2021. Composting: phases and factors responsible for efficient and improved composting. Agriculture and food E-newsletter 3 (1), 8690.

Mujiyo, W. H. Herawati, A. Rochman, F. and Rafirman, R. 2017. potensi lahan untuk budidaya pisang Di Kecamatan Jenawi Karanganyar. Sustainable Agriculture 32(2), 142-148.

Natalina. Sulastri. and Aisah, N.N. 2017. Pengaruh variasi komposisi serbuk gergaji, kotoran sapi dan kotoran kambing pada pembuatan kompos 1 (2).

Nuriasih, P. D. Putra, I. K. Asih, N. K. and Pratiwi, L. P. 2019. Pemanfaatan limbah kulit pisang sebagai masker kecantikan organik. Bakti Saraswati 8(2), 150-154.

Olle, Margit. 2019. Review: vermicompost, its importance and benefit in agriculture. Agricultural Science 2, 93-98.

Othman, N. Irwan, J.M. Roslan, M.A. 2012.Vermicomposting of food waste. International Journal of Integrated Engineering. 4, 39-48.

Rahmatullah, F. Sumarni, W. and Susatyo, E.B. 2013. Potensi vermikompos dalam meningkatkan kadar $\mathrm{n}$ dan p pada limbah ipal pt. djarum. Indonesian. Chemical Science 2(2), 142-147.

Rahmawati, E. Herumurti, W. 2016. Vermikompos sampah kebun dengan menggunakan cacing tanah edrilus eugeneae dan eisenia fetida. Teknik Lingkungan 5(1).

Singh. Jaswinder. Singh, S. Vig, A. P. and Kaur, P. 2018. Environmental influence of soil toward effective vermicomposting chapter 3. effect of temperature and moisture on earthworm in the ecological engineers of soil. London. IntechOpen.

Subandriyo. Anggoro, D. D., and Hadiyanto. 2012. Optimasi pengomposan sampah organik rumah tangga menggunakan kombinasi aktivator $\mathrm{EM}_{4}$ dan $\mathrm{MOL}$ terhadap rasio $\mathrm{C} / \mathrm{N}$. Ilmu Lingkungan, 10(2), 70-75. 
Suhartanto, M. R. Sobir. and Harti, H. 2012. Teknologi sehat budidaya pisang: dari benih sampai pasca panen. Bogor. Pusat Kajian Hortikultura Tropika, LPPM-IPB.

Suprianto, and Erlani. 2019. Proporsi sekam padi dalam pembuatan kompos limbah kulit pisang.

Sulolipu Media Komunikasi Sivitas Akademika dan Masyarakat 19(1), 34-42.

Purnomo. Eko A. Sutrisno, E. Sumiyati. 2017. Pengaruh variasi c/n rasio terhadap produksi kompos dan kandungan kalium, pospat dari batang pisang dengan kombinasi kotoran sapu dalam sistem vermicomposting 6 (2).

Tchobanoglous, G., Theisen, H., and Vigil, S. 2002. Integrated solid waste management. New York: McGraw-Hill.

Wulandari, N. D. 2020. Pengolahan sampah daun mangga, daun trembesi dan sayuran dengan metode vermikompos. Tugas Akhir, Politeknik Perkapalan Negeri Surabaya. 